\title{
EU-China-Africa Trilateral Development Cooperation: A Global Governance Perspective
}

\author{
Xiaoying Dong ${ }^{1, *}$ Chenghong Jiang ${ }^{2}$ \\ ${ }^{1}$ School of Marxism, Tongji University, Shanghai 200092, China \\ ${ }^{2}$ Institute of Applied Economics, Shanghai Academy of Social Sciences, Shanghai 200020, China \\ *Xiaoying DONG.2031937@tongji.edu.cn
}

\begin{abstract}
Global issues are becoming increasingly severe, and the role of international aid as a public product in global governance is becoming increasingly apparent. Based on the real needs of global governance, this study explores the significance and future directions of China and the EU cooperation in Africa. To answer this question, we introduce the situation of China and the EU's development cooperation. Our results showed that EU-China-Africa cooperation faced three problems. Results also revealed that tripartite cooperation is necessary. In the future, though, the tripartite cooperation model needs to be modified. From a global governance perspective, this study emphasizes the need to take into account the impact of global issues and the appropriate means of Africa's assistance rather than competition.
\end{abstract}

Keywords: Global Governance, European Union-China-Africa, International Aid, Development Cooperation.

\section{INTRODUCTION}

General Secretary Xi Jinping gave a key assessment of the current international situation, 'our world is experiencing profound changes unseen in a century.'Amid these once-in-a-century changes, global issues are constantly emerging global issues (e.g., economic crises, terrorism, infectious diseases, sustainable development problem cybersecurity) lead to global crisis. Thus, global governance has become a shared issue facing the international community. As an instrument of global governance, international aid had become an integral and critical field of global governance research [1]. Besides, the EU (European Union) and China are the principal actors of global governance, so both have the primary responsibility for global governance [2].

Consequently, the EU and China should carry out practical cooperation in global governance, especially in international aid [2]. Additionally, apart from global governance or development cooperation, Africa is at the centre of China's and Europe's concerns in that addressing Africa's development issues is the key to addressing global development issues [3]. Thus, the EU and China's development cooperation in Africa is an essential topic in global governance.

Recent work has shown that European scholars were interested in the EU- China- Africa cooperation. Some scholars (e.g., Bernt Berger, Maurizio Carbone) rethought the relationship between the EU and Africa owing to Chinas' successful international aid plan in Africa. However, these articles generally considered cooperation among the three from the perspective of Eurocentrism. On the one hand, academics had shown the enthusiasm of the three cooperation. On the other hand, researchers had shown distrust towards China because they believed China is a competitor to the EU. They thought that the EU is more likely to be a benign partner for Africa, whereas China is not due to China's countermoves without caring much about Africa's sustainable development strategies [4].

We have previously introduced that the significance of exploring the EU - China-Africa cooperation is beneficial to global governance. Nevertheless, the analysis of tripartite cooperation from the viewpoint of a 
state-cantered or Eurocentric model is not conducive to the cooperation of the three because national interests restrict global governance. Here, this study focuses on the perspective of global governance to see the significance and future directions of China and the EU's development cooperation in Africa. Distinct from previous studies, this study focuses on the ethics of shared responsibility to consider global governance, which means that this paper will not contain Eurocentrism. The paper will be organized as follows: the first section will explain what global governance theory is selected. The following section will introduce the situation of China and the EU's development cooperation in Africa. Another section will clarify the significance of the trilateral cooperation. The last section will be followed by a brief exploration of future direction among the three.

\section{LITERATURE REVIEW}

The research of EU-China-Africa trilateral development cooperation is an emerging area in international politics. Previous papers on the relationship between China and the EU in Africa focused on introduction, experiential review and evaluation. Some scholars explored questions about the situation of China's international aid in Africa (e.g. Carol Lancaster 2007; Pehnelt, G. 2007; Gregory T. Chin \& B. Michael Froic 2007; Martyn Davies 2008; Thomas Lum 2009; Chaponnière 2009; Sven Grimm 2011; Sara Lengauer 2011; Shimomura, Y. and Ohashi, H. 2013). For instance, the policy of aid, volume of aid, and aid institutions is the main object of previous studies.

Using China statistical yearbook is the universal method to find the situation of international aid of China. However, some scholars claimed that data transparency is a questionable issue because of differential statistical methods between China and western countries [5-6]. Data transparency of international aid had become another academic concern. After that, a systematically database analysis of international aid of Chinese international aid had surveyed by Grimm's team. Grimm et al., reported that Chinese traditional culture and philosophy are also key elements leading to data transparency of international aid, but they also captured the gradual transparency of data [7]. Also, 'Rogue aid? The determinants of China's aid allocation' pointed out that empirical research says that improving the data transparency of international aid is a beneficial method to resolve suspicions from other countries [8]. From this, scholars have given a systematic introduction with data to China's international aid in Africa.

According to the data collection and analysis, China's international aid's effect and evaluation had become the latest academic hotspot. The first awareness is criticism and suspicion. Data transparency and aid motivation were fluently and heavily criticized. Naim suggested that china's international aid is undemocratic and opacity in essence and practice [9]. The recipient country, China, slowed down the domestic reform and development because China government provide resources without extra political condition, which also bring the problem of resource dependency [9]. Additionally, unconditional aid from China put pressure on traditional recipient countries [10]. China's international aid failure to comply with existing potential aid rules has led to an unacceptable crowding-out effect on traditional recipients' countries.

Nevertheless, without any data showed that the relationship between the China's international aid and corruption and poverty in Africa had formed a positive correlation. The second point is supported. Actually, the successful cases of pushing democratic reform in Africa due to conditional aid from the traditional recipients' countries were individual cases [11]. Additionally, the industrial infrastructure is the advantage of China. The project of building railroads, dams and schools was taken in Africa, which could not only help African countries secure other loans and investment opportunities [12], but also could hire Chinese and African workers simultaneously to improve technology and reduce human capital [11]. In brief, although there is some controversy among them, the scholars' evaluation has objectivity thanks to the prevalence of positivism. Statistics and interviews are commonly used with regard to China's international aid to Africa.

For traditional recipient countries, whether China, an emerging recipient country, is an adversary or a collaborator has become the subject of discussion. Nevertheless, predictably, all of them concentrate on Africa because Africa's development is the key to dealing with global issues. Thus, the possibility, availability and difficulty of collaboration among them is the latest research area. From the perspective of the EU, Carbone indicated that the cooperation project was actually going to run counter to that realistic tendency [13]. Carbone considered that the rise of China in Africa broken the balance of the international aid system [13].

Hence, for the EU, the adoption of a new strategy was inevitable and placed Africa high on the agenda of the EU. From the perspective of geopolitics or a European research perspective, Staeger affirmed that a reemergence of China on the international scene and a more prosperous African continent had been witnessed. For the EU, China is a major challenge [14]. The EU showed "fears" over China's interaction with African countries. While this presumption is slowly shifting and growing demands for engaging China as a "partner" or "responsible stakeholder" in Africa's growth and security, the idea that China is an implicit threat to the West's supremacy is deeply ingrained. The different attitude of cooperation had exposed deep divisions within EUChina-Africa trilateral development cooperation.

Moreover, according to the case study, the aid effect of South-Africa, an equivalent partner to China and the 
EU in a trilateral setting, was far from the expected standard [15]. In short, scholars founded the benefits of trilateral development cooperation, but hidden west position (Eurocentrism) may bring cultural misreading and high levels of anxiety tendency of china's international aid in Africa. Abegunrin \& Manyeruke still concluded that the behaviour of unconditional help to Africa had threaten the development of democracy, transparency, liberalism and free trade [16]. Uncertainty, China's political influence and security presence in Africa were to expand, the heightened sense of competition between China and Western countries [16], which similarly shows that scepticism and unease still pervade the EU-China-Africa trilateral development cooperation. In spite of some insightful EU-China-Africa trilateral development cooperation model studies, it remains hidden western position when it comes to the China's international aid in Africa. To fill the research gap, the paper discusses the signifiance and future directions of development cooperation from the perspective of global governance.

\section{THEORETICAL FRAMEWORK}

Global governance is the most attractive conceptual system in a globalized world. Considering that global governance characteristics have diversified, there is no clear global governance concept [17]. Though the definition is not clear, three global governance theory have been recognized. Three large accounts of the essence and sense of contemporary globalization referred to here as the hyperglobalist, the skeptical, and the transformationalist perspectives lie behind the language of globalization - rhetoric used in popular and scholarly discourse [18].

(1) Hyperglobalists maintain that we live in an increasingly global world in which states are subjected to massive economic and political change processes. It erodes and splinters nation-states and reduces the power of politicians. Under such circumstances, states are increasingly the 'decision-takers' rather than the 'decision-makers.'

(2) Skeptics strongly disagree with this view and believe that contemporary world circumstances are not without precedent. In their view, while international and social activity has intensified in recent times, this has strengthened states' powers in many areas.

(3) Transformationists argue that globalization creates new economic, political, and social circumstances that, albeit unequally, serve to transform the state's powers and the context in which states operate. They do not predict the outcome- they think it is uncertain - but argue that politics is no longer, and can no longer be, based on nation-states.

Held et al. also used the table to carefully illustrate three tendencies of globalization in 'Global transformations: Politics, economics, and culture.' After that, some theorists have commented on these [18]. Wang claimed that these three tendencies have obvious differences and common characteristics [19]. From a common perspective, the three believe that the nationstate governance model cannot cope with globalization's different problems. When it comes to differences, the three tendencies have different objectives. Skeptics believe that decentralization and the role of local, community, and non-governmental organizations are essential. Hyperglobalists and Transformationists acknowledge the effectiveness of the international system. Transformationists are concerned about the reconstruction of the global governance structure and play the role of individuals, countries, and nongovernmental organizations.

Though Wang also criticized that hyperglobalists' concept, such as the national centre concept, is impossible to explain global politics' complexity after the cold world perfectly, hyperglobalism is the mainstream view of global governance theory [19]. Additionally, Jiang mentioned that the EU's role in global governance could not be ignored because the EU has consistently maintained a position behind the U.S. in global governance. The Americans, the Chinese, and even the Europeans have underestimated the EU power and their international activities [2]. Simultaneously, China, an emerging power and emerging donor, must learn some experiment with the traditional donor- the EU. Furthermore, the paper will focus on cooperation among the three. The EU accepts global governance's mainstream theory: hyperglobalism, which means that China is not likely to get the EU accession providing China abandoned the mainstream concept of global governance.

The phenomenon cannot, however, be ignored. The EU and China have different concepts in global governance. The EU, China, and African countries should find a common concept if they hope to cooperate. Compared with other viewpoints, hyperglobalism is generally recognized among the three. Jiang also affirmed that respecting sovereignty, maximizing the absorption of all forces that can be absorbed, obeying the UN leaders, and fostering multilateral relations are common principles for these countries [2]. In parallel, cooperation between the EU and China is also conducive to African development [2]. Given that hyperglobalism is normally recognized among the three, this paper will explore the significance of China and the EU's cooperation in Africa and the future development direction under hyperglobalists' global governance concept. 


\section{THE SITUATION OF CHINA AND THE EU'S DEVELOPMENT COOPERATION IN AFRICA FROM THE PERSPECTIVE OF GLOBAL GOVERNANCE}

The development of cooperation between the EU and China in Africa is a typical tripartite development cooperation model. Development cooperation among the three stems from the strategic balance of the EU with China and Africa. Even though the original reason for cooperation is a passive attitude, the EU and China's development cooperation in Africa is an enthusiastic attitude according to global governance since Africa countries expect that the EU and China provide affluent resources such as medicine, technology, and capital. For Africa, China represents the development of new business and political partnerships. The conventional concept of the EU's international aid and development on the continent also led to discontent among African countries. Thus, the complementarity between the respective approaches of these two to the continent has been noted by some academics and policymakers [20].

There are some problems with cooperation. Though the EU, China, and African countries declared that the UN's framework was the basis of cooperation, in real operations, they might not strictly follow the UN guidelines, and there was a lack of dialogue among the three [21]. Moreover, Berger and Wissenbach worried that whether Africa can manage its multiple partnerships becomes an (increasingly integrated) actor rather than remaining an object of great power agendas [4]. The third problem is the insufficient participation of African countries, which indicates that China and the EU aid African countries under their own strategic goals. Likely, the EU and China might not understand clearly what the needs of African countries are. Any undertaking that excludes African states may improve Africa's international passivity [4].

In summary, the cooperation between the EU and China is of great significance to promoting Africa's development. However, the lack of communication, the lack of understanding of African countries' willingness in practice, and Africa's impossibility to become the dominant player are the main reasons for cooperation problems. It is undeniable that the cooperation of the three is meaningful for global governance.

\section{SIGNIFICANCE OF CHINA AND THE EU'S DEVELOPMENT COOPERATION IN AFRICA FROM THE PERSPECTIVE OF GLOBAL GOVERNANCE}

\subsection{Achievement of a variety of expectations}

The cooperation of the three can reduce the EU's worry about penetrating China's power in Africa.
Moreover, all receive mutual and win-win advantages. Firstly, African countries can get the EU and China's fund and acquire leadership and ownership to enhance their constitution. The most favorable point is that African countries may obtain the most beneficial interests for their countries between the EU and China. Second, the EU also hopes to reduce the burden from aiding funds due to economic weakness. Thus, The EU hopes that China joins the Africa aid plan because China is the world's second-largest economy.

Likewise, the EU includes China in the international aid system, enabling China to comply with existing rules to keep the EU dominant in global governance. Comparative advantage also another point is considered. Relatively, China's human capital is inferior to that of European countries. The EU can cut down some aiding funds in Africa countries again. Third, China expects to increase its influence in Africa and get aiding experience from the EU. The most crucial point was that China hopes to grow in strength to influence existing aid rules and become one of the main actors [22].

\subsection{Providing international public goods for global governance}

Prior to the explanation of Jayaraman and Kanbur, international aid was also international public goods [23]. A new basis for interpreting and examining international aid could be provided by the procurement of public goods and transnational externalities adjustment [24]. Ferroni and Mody also declared that international aid is a core and complementary activity to prompt market and regional programs' cooperation [25]. For example, the United Nations Development Programme (UNDP) was the leading knowledge-based organization for sustainable development within the UN development system. It serves as an integrator for collective action to achieve the Sustainable Development Goals (SDGs) [26].

UNDP, Organisation for Economic Co-operation and Development (OECD), and World Bank (WB) has provided a series of international aid. Swiss claims that international aid had the phenomena of globalization, which means that many countries had agreed with aid behaviour from UNDP, OECD, and W.B [27]. International aid had been recognized as an international public good. From the perspective of global governance theory in hyperglobalism, the purpose of international aid is development. International aid could resolve the impact of world problems caused by internal development problems from this country [28]. Africa countries consider development cooperation to be in line with their national security strategy. The EU and China provide international aid as a strategy for global governance. Therefore, the EU and China to provide aid in Africa's development is a significant way to provide international public goods. 
Nevertheless, Olson asserted that the customary view that groups of the individual with common interests appears to have little if any merit [29]. Olson's statement was strongly worded. It cannot be ignored that the beneficiaries of potential collective actions in collective action to get a free ride while hesitating to leave any more free ride. A typical example was that three monks have no water to drink [26]. Pang provided a solution to Olson's collective action dilemma. Pang stated that binding private property and public goods could realize the supply of public goods [30]. Effectively defining property rights limits could guarantee different motivations and expectations among the EU, China, and Africa [30]. Based on current bilateral frameworks, complemented by tripartite cooperation to sustain structured cooperation, China and Europe would fully foster Africa's growth and benefit from introducing international development governance [3]. There is evidence that development cooperation between China and the EU in Africa contributes to international public goods in global governance. Common interests appears to have little if any merit.

\subsection{Realization of the sustainable development agenda}

Sustainability is the goal of all humankind. China and the EU have also released a joint statement outlining the objective of promoting global sustainable development. From the UN's official document, the UN had mentioned seventeen sustainable development and 169 specific goals [31]. The achievement of sustainable development requires that the international community assumed its own responsibilities. International aid is one of the primary means of fulfilling international social responsibility. Despite that international aid does not really resolve developing countries' problems, the value and importance of international aid cannot be easily denied. Learning from prior experience and improving international aid is to achieve sustainable development at the UN in 2030.

Simultaneously, Africa countries would focus on 'Agenda 2063' to achieve inclusive growth and sustainable development at the level of African countries, regions, and continents. The program is an African global strategy that can be formulated in line with resource utilization throughout Africa. The program is a long-term plan. Africa is currently in the first phase of the program. Cooperation between the EU and China is crucial to the realization of this program. From global governance, the '2030 Agenda' realization is a crucial direction of global governance. From the perspective of African development, the '2063 Agenda' respond more closely to African development needs. Therefore, it is more realistic to compare and evaluate the ' 2030 Agenda of the UN and the '2063 Agenda' of Africa and determine similar priorities for developing international aid for the EU,
China, and Africa. The UNs' sustainable development plan and the different goals are combined and focus on common interests for development, promoting sustainable development.

\subsection{Improving the quality and effectiveness of international aid}

Since the 21 st century, aid effectiveness has become a key measure of international development aid. In 2006 , each recipient country received an average of 28 aids from donor countries [32]. In 2007, the number of aid missions in 54 recipient countries reached 15,000. Statistics from the 2008 Accra Aid Effectiveness Conference in Ghana showed that the number of bilateral ODA projects soared from 10,000 10 years ago to 80,000 [33].

However, given many projects and aid missions, the beneficiary countries were busy receiving numerous delegations from aid agencies and discussing various projects [34]. The lack of cooperation and collaboration structures between many organizations had resulted in a doubling of aid work and substantial pressure on recipient countries regarding finances, personnel, and material resources [34]. In short, recipient countries have difficulty meeting the criteria for projects proposed by donor countries. The donor countries also spent a great deal of money and even invested several times. International aid should enhance quality and efficiency.

\section{FUTURE DIRECTIONS OF CHINA AND THE EU'S DEVELOPMENT COOPERATION IN AFRICA FROM THE PERSPECTIVE OF GLOBAL GOVERNANCE}

Nowadays, the practice and discussion of EU-China development cooperation in Africa are more research from EU-China policy in Africa. Although its exploration and experimentation have formed a relatively stable cooperation method, from global governance, developing cooperation between the EU and China in Africa requires even greater attention to global issues. China-Africa cooperation research needs to highlight African countries' leading position and deepen current frameworks for bilateral and multilateral cooperation.

\subsection{Focus on Global Issues}

The core of global governance is dealing with global issues. EU-China cooperation to resolve global problems that could spill over within Africa has both self-interest and altruism in this interdependent world. The EU and China have a strong connection to the economic development and political stability of Africa. A turbulent and impoverished Africa will inevitably cause insecurity in Sino-European cooperation. To avoid an 
interdependent world becoming a dangerous one, cooperation between the EU and China on development in Africa should focus on Africa's global development issues. The social system of most countries in Africa is severely insufficient due to the backward economic growth. African people are usually impoverished. The national governance level is low, offering a fertile ground for various global concerns (e.g., epidemics, extreme terrorism, atmospheric pollution, illicit migrants). These problems have gradually spread to other countries and regions, bringing a certain degree of negative externality and ultimately evolving into global issues.

There are four areas of consensus between the EU and China regarding development cooperation with Africa (Humanitarian rescue of natural disasters and epidemic infectious diseases; Maintenance of peace and security, climate change issues; Development and construction of "soft" social governance). Central Europe was founded in 2012 Emergency Management Institute, aimed at strengthening assistance for natural disasters, outbreaks of disease, and food shortages and strengthening humanitarian relief for African countries. The 'EU-China leaders' statement on climate change and clean energy' statement illustrates how the EU and China would step up their diplomatic, technological, economic, and scientific collaboration on climate change and renewable energy in order to advance the worldwide transition towards a thriving low-carbon and environment-resilient economy and society and clean energy infrastructure. The statement also indicated that it would discuss the possibility of fostering trilateral collaboration in other developing countries, including Africa, such as renewable energy, energy conservation, and low greenhouse gas emissions. The EU and China would strengthen their ability to cope with climate change [35]. The statement also indicated that it would discuss the possibility of fostering trilateral collaboration in other developing countries, including Africa, on access to renewable energy, energy conservation, and low greenhouse gas emissions, and to help them strengthen their ability to cope with climate change [36].

In the 'soft' field of social governance, the EU underlines the construction of a social system of 'good governance,' while China stresses human resources' development without political conditions [3]. This divergence of ideas should be filled with a shared experience of development. The EU, through nongovernmental organizations, has provided a social sphere and comprehensive support for poverty alleviation and rural development in remote and poor rural areas of China [3]. These aid modalities become part of China's social development experience in China after the practice's success. Overall, with the sharing of the EU experience to support China, the EU and China can promote social development and governance in Africa.

\subsection{Underline the leadership role of African countries}

The support of Africa is a prerequisite for the triangular development cooperation of the three. In 2009 the parties ' $\mathrm{G} 8+5$ Heiligendamm Process Development Working Group Meeting' and the document of 'EUChina leaders' statement on climate change and clean energy in 2018 had told that the EU and China would discuss triangular collaboration possibilities to encourage renewable energy access, energy conservation and the production of low greenhouse gas emissions in other developing countries. Cooperation will enable them to expand their capacity to fight climate change, emphasizing the least developed countries, small island developing countries, and African countries, as expressed in their efforts to tackle climate change [37]. Furthermore, if African-led, the benefits of a trilateral approach lie in exploiting African policies' synergies and complementarity between the EU and China [4]. In short, tripartite cooperation should be based on the recipient's needs, fully respect the recipient's wishes, and play a leading role in the cooperation.

Besides, African countries' rich natural resources and potential markets are highly attractive to China and Europe, giving them an advantage of negotiation to obtain development resources [3]. Simultaneously, Africa is geographically close to Europe, so Europe has to actively provide development assistance resources to Africa for its strategic security interests [3]. Many developing countries in Africa are the "ballot box" of international organizations such as the United Nations, which means that it is of great strategic importance for China and Europe to get assistance from Africa to achieve foreign influence [33]. The spread of global issues in the world has forced China and Europe to increase their attention and investment in Africa's "government depression" to achieve effective global governance [3]. Though African countries are in a weak position in the overall power structure, Africa has a more flexible power edge in specific areas. It is therefore possible, in theory and practice, for Africa to occupy a leadership position in tripartite cooperation.

\subsection{Strengthen bilateral and multilateral cooperation mechanisms}

Building upon existing bilateral and multilateral mechanisms is a realistic choice for China and Europe to develop cooperation in Africa. The nascent 'South-NorthSouth' cooperation would focus on the UN, the ChinaAfrica Cooperation Forum, and the China-Africa Cooperation Forum to facilitate implementation and make it more operational because of the complexities of global problems and the flattening of the international power structure. It is not hard to realize that the UN is a cooperative mechanism agreed to by the EU and China. 
Both sides have consistently reaffirmed the UN's essential role in global governance and the realization of sustainable development goals. At the same time, pragmatic exchanges and collaboration within the UN system have been emphasized. The UN is a chief body for solving international political, economic, social, cultural, or humanitarian problems.

Additionally, the international legitimacy of the UN is more likely to gain the confidence of African countries. The EU-African Cooperation Forum and the ChinaAfrica Cooperation Forum provide important platforms for North-South cooperation and South-South cooperation. Tripartite cooperation on that basis is more achievable. The EU and Africa: towards a strategic partnership had been published in 2005, which means that the EU would change their attitude toward Africa countries. This document would be the whole of the EU for the whole of Africa, and its underlying philosophy is African ownership and responsibility, including working through African institutions [38]. It means that African countries are seen as equal political partners and provide a comprehensive and long-term framework for future African development policies. Since the creation of the China-Africa Cooperation Forum in 2000, bilateral relations have entered a new era of comprehensive and institutionalized strategic partnership [3]. During the forum, China would announce three-year aid measures and implement them through action plans.

Furthermore, according to the 'Africa-proposed, Africa-agreed and Africa-led' concept and with an engaged, transparent and inclusive mindset, collaboration and cooperation with other countries and international and regional organizations can be strengthened [39]. The passage has been mentioned in China's second Africa policy paper. China's international aid to Africa is also on account of a partnership principle. In brief, China-EU cooperation in Africa joins the UN as the main platform and actively participates in the UN sustainable development plans.

\section{CONCLUSION}

The main goal of the current study was to determine the significance of China and the EU's development cooperation in Africa from the perspective of global governance. The second aim of this study was to investigate future direction development cooperation in Africa among the three sides from the perspective of global governance. This study has identified that the EUChina - Africa cooperation had a vital value. From global governance, the EU and China and development cooperation with Africa results mainly in four aspects. Firstly, tripartite cooperation can have a positive impact on their strengths. For the EU-China - Africa, the most crucial thing is to achieve a win-win outcome. The EU uses comparative advantages to reduce the pressure on funds after the economic crisis. China also hopes to find the opportunity to enhance its influence in Africa. Of course, Africa countries can get the maximum gains between them. Next, the cooperation of the three contributes to realizing the supply of public goods in global governance. The cooperation of three avoids Olsen's theory of collective action through the regrouping and cooperation of private and public goods.

Third, tripartite cooperation can realize the sustainable development agenda. From the perspective of global governance, sustainable development is the millennium plan of humankind. With a view to the ChinaAfrica Forum and the EU-Africa Forum, the promotion of Africa's sustainable development is the strategic objective of the two sides. Certainly, the 2063 Agenda, a grand blueprint for achieving sustainable development and economic growth in Africa, is the goal of Africa's sustainable development. Hence, the three sides look forward to achieving sustainable development through global governance. Lastly, tripartite cooperation conducive to international aid efficiency. To a large extent, the differences between the EU's and China's policy towards Africa can lead the EU-China competition in Africa, especially in energy and environmental security and business [4]. Mutual cooperation and coordination between the EU and China can enhance the effectiveness of international aid. Cooperation can reduce the waste of international aid resources and increase their respective advantages.

Around China's cooperation with Africa, the EU perceptions of China's engagement with Africa have been fairly, sometimes extremely negative [40]. One of the more significant findings to emerge from this study is that the EU should give up their prejudices against China and concentrate on global issues. Concentrating on global issues have significant implications for the EU-ChinaAfrica cooperation. As mentioned above, solving global issues is the core of global governance. China and the EU are expected to focus on the global problems caused by poverty and unrest in Africa. Competition between the EU and China cannot promote social development in Africa and global governance. Additionally, the EU and China must change their mindset and role to aid Africa. A basic requirement for tripartite collaboration is to emphasize the leadership position of African nations. Lastly, for the EU and China, relying on the existing bilateral and multilateral cooperation mechanism is an effective way (e.g., the UN, China-Africa Forum, the EUAfrica Forum, the EU- China Forum) to promote development cooperation in Africa. A limitation of this study is that this paper does not use credible evidence (e.g., data) or events (e.g., cases) to show the viability of the EU-China development cooperation in Africa. Notwithstanding these limitations, the study suggests that it is feasible to study the future direction of the EU- China cooperation from global governance. Further research should be undertaken to explore the future direction of the EU-China cooperation in Africa through empirical 
analysis. To conclude, providing we consider the cooperation among the three in terms of global governance, Africa's development aid will be more effective and of high quality. International aid or development cooperation from the EU and China to Africa requires a global governance perspective to examine its challenges to ensure effective cooperation.

\section{REFERENCES}

[1] Zhou, H., Zhang, J., \& Zhang, M. Foreign aid and development: Taking China's aid experience as an example[Wai Yuan Yu Fa Zhan: Yi Zhong Guo De Shou Yuan Jing Yan Wei Li]. Chinese Journal of European Studies, 02, 2007, pp.1-20. DOI: CNKI:SUN:OZZZ.0.2007-02-000.

[2] Jiang, Sh. X.. China-EU Cooperation in global governance: Concept, actions and areas of cooperation [Quan Qiu Zhi Li Zhong De Zhong Guo Yu Ou Meng: Guan Nian, Xing Dong Yu He Zuo Ling Yu]. China Social Sciences Press, 2016.

[3] Yan, S. H., \& Lai, X. Y. The European Union and Global Governance (Ou Meng Yu Quan Qiu Zhi Li). Social Sciences Academic Press (China), 2020.

[4] Berger, B., \& Wissenbach, U. EU-China-Africa trilateral development cooperation: Common challenges and new directions: German Development Institute / Deutsches Institut für Entwicklungspolitik (DIE). (Reprinted), 2007.

[5] Lum, T.. China's assistance and governmentsponsored investment activities in Africa, Latin America, and Southeast Asia, 2009.

[6] Paulo, S., \& Reisen, H. Eastern donors and western soft law: Towards a DAC donor peer review of China and India? Development Policy Review, 28(5), 2010, pp.535-552. DOI:https://doi.org/10.1111/j.14677679.2010.00497.x

[7] Grimm, S., Rank, R., Schickerling, E., \& McDonald, M.. Transparency of Chinese Aid: An analysis of the published information on Chinese external financial flows, 2011, DOI: http://hdl.handle.net/10019.1/21430

[8] Dreher, A., \& Fuchs, A. Rogue aid? The determinants of China's aid allocation. The Determinants of China's Aid Allocation (September 6, 2011). Courant Research Centre Discussion Paper, 2011, p.93. DOI: https://doi.org/10.1111/j.14682346.2008.00765.x

[9] Naim, M. (2007). Rogue aid. Foreign Policy, 159, p.96.DOI:https://search.proquest.com/docview/224 026979/2B4F2E0A381549C3PQ/1\#
[10] Manning, R. Will 'emerging donors' change the face of international co-operation? Development Policy Review, 24(4), 2006, pp.371-385. DOI: https://doi.org/10.1111/j.1467-7679.2006.00330.x

[11] Lengauer, S. China's foreign aid policy: Motive and method. Culture Mandala, 9(2), 2011, pp.58-99. DOI:http://epublications.bond.edu.au/cm/vol9/iss2/ 3

[12] Chaponnière, J.-R. Chinese aid to Africa, origins, forms and issues. The New Presence of China in Africa, 2009, pp.55-82. DOI: https://library.oapen.org/bitstream/handle/20.500.1 2657/35313/340012.pdf? sequence $=1 \#$ page $=56$

[13] Carbone, M. The European Union and China's rise in Africa: Competing visions, external coherence and trilateral cooperation. Journal of Contemporary African Studies, 29(2), 2011, pp.203-221. DOI:https://doi.org/10.1080/02589001.2011.55519 5

[14] Staeger, U. EU-China-Africa Trilateral Relations in a Multipolar World: Hic Sunt Dragones. HeinOnline, 2018.

[15] Stahl, A. K.. Trilateral development cooperation between the European Union, China and Africa: What prospects for South Africa?2012. DOI: http://hdl.handle.net/10019.1/70766

[16] Abegunrin, O., \& Manyeruke, C. China's Power in Africa (1st ed.), 2020, British: Palgrave Macmillan.

[17] Finkelstein, L. S. What is global governance? Global Governance: A Review of Multilateralism and International Organizations, 1(3),1995. pp.367372. DOI: https://doi.org/10/gf2pf4

[18] Held, D., McGrew, A., Goldblatt, D., \& Perraton, J. Global transformations: Politics, economics and culture. In Politics at the Edge, 2000. pp. 14-28. Springer.

DOI: https://doi.org/10.1057/9780333981689_2

[19] Wang, M. G. Introduction to Global Governance (Chinese Edition). Beijing: World Affairs Press, 2019.

[20] Kotsopoulos, J. The EU and Africa: A Multilateral Model for the Future of Africa-China Relations? In Africa-China Cooperation, 2020. pp. 215-233. Springer. DOI: https://doi.org/10.1007/978-3-03053039-6_10

[21] Alden, C., \& Sidiropoulos, E. Africa-China-EU cooperation in Africa: Prospects and pitfalls. Sweden: Nordiska Afrikainstitutet, 2009. 
[22] Li X. Y.. International Development Aid: China's Foreign Aid [guo ji fa zhan yuan zhu: zhong guo dui wai yuan zhu]. China: World Affairs Press, 2015.

[23] Jayaraman, R., \& Kanbur, R. International Public Goods and the Case for Foreign Aid WP, 1999, pp.99-05, Reprinted. DOI: 10.22004/ag.econ.127684

[24] Kanbur, S. R., Sandler, T., \& Morrison, K. M. The future of development assistance: Common pools and international public goods (Vol. 25). Overseas Development Council Washington, DC, 1999.

[25] Ferroni, M., \& Mody, A. International public goods: Incentives, measurement, and financing. Springer Science \& Business Media, 2011.

[26] UNDP Coordination and Management Support Consultant for UNDP Sida Environment and Climate Change Programme, 2020. https://jobs.undp.org/cj_view_job.cfm?cur_job_id= 90948

[27] Swiss, L. The globalization of foreign aid: Global influences and the diffusion of aid priorities. In The Palgrave Handbook of Development Cooperation for Achieving the 2030 Agenda, Palgrave Macmillan, Cham, 2021, pp. 113-125. DOI: https://doi.org/10.1007/978-3-030-57938-8_6

[28] Olson, M.. The Logic of Collective Action [1965]. Contemporary Sociological Theory, 124, 3rd ed., United State: Wiley-Blackwell, 2012.

[29] Pang, X. Overcoming the dilemma of collective action in international public goods [Guo Ji Gong Gong Chan Pin Zhong Ji Ti Xing Dong Kun Jing De $\mathrm{Ke} \mathrm{Fu}$. World economics and politics, 07, 2012, pp.24-42.DOI: CNKI:SUN:SJJZ.0.2012-07-004.

[30] Transforming our world: The 2030 Agenda for Sustainable Development | Department of Economic and Social Affairs, 2015. https://sdgs.un.org/2030agenda

[31] Knack, S., \& Smets, L.. Aid tying and donor fragmentation. World Development, 44, 2013, pp.63-76. DOI: https://doi.org/10/ghsbfj

[32] Co-operation, O. for E. \& Development. Business for Development 2008: Promoting Commercial Agriculture in Africa. OECD Publishing, 2008.

[33] Tang, L. X., Wu, J., \& Li, X. X.. The international community's agricultural development assistance to Africa [Guo Ji She Hui Dui Fei Zhou De Fa Zhan Yuan Zhu]. World Agriculture, 07, 2011, pp.51-56. DOI:CNKI:SUN:SJNY.0.2011-07-013

[34] EU and China step up cooperation on climate change and clean energy | European Commission,
2018. https://ec.europa.eu/info/news/eu-and-chinastep-cooperation-climate-change-and-clean-energy2018-jul-16_en

[35] EU, China agree to work together on clean energy. (2019, April 10). Climate Home News. https://www.climatechangenews.com/2019/04/10/e u-china-agree-work-together-clean-energy/.

[36] EU and China agree sweeping joint statement on climate action. (2018, July 16). Climate Home News. https://www.climatechangenews.com/2018/07/16/e u-china-agree-sweeping-joint-statement-climateaction/

[37] Barnett, M., \& Duvall, R. Power in international politics. International Organization, 59(1), 2005, pp.39-75. DOI: https://doi.org/10/bvhm29

[38] Refworld | The EU and Africa: Towards a Strategic Partnership. (2005). Refworld. https://www.refworld.org/docid/43e1fde04.html

[39] China's second Africa policy paper. China.Org, 2015.http://www.china.org.cn/world/201512/05/content_37241677.htm

[40] Tull, D. M.. China in Africa: European perceptions and responses to the Chinese challenge. Washington, DC: The Johns Hopkins University, 2008. 